\title{
Traditional music protection from the perspective of intangible cultural heritage
}

\author{
Jie Zhang* \\ Nanyang Normal University Nanyang Henan 473061, China.
}

\begin{abstract}
Music is a very important part of national culture, and also an important intangible cultural heritage. In the contemporary era of rapid economic development and increasingly prosperous exchanges between China and the west, the inheritance and promotion of national music has attracted unprecedented attention and become an important topic in the protection of intangible cultural heritage in China. Starting from the context of intangible cultural heritage, this paper analyzes the key points of inheritance and promotion of national music in the context of intangible cultural heritage, hoping to contribute to the protection of intangible cultural heritage in China.
\end{abstract}

Keywords:Intangible cultural heritage; National music; Inheritance and promotion

\section{Introduction}

With the changes of the times, the traditional ethnic production and living scenes have changed greatly. The original structure of ethnic music creation, inheritance and development has been disintegrated, and the soil for the growth and prosperity of ethnic music has been impacted. Under the influence of western music and modern music, the living space of ethnic music, especially ethnic music, is becoming increasingly narrow, which brings about the protection of intangible cultural heritage Certain challenges and problems. In the process of protecting the intangible cultural heritage of national music, we should first of all carefully divide the key content, key content and basic content of national music, dig out the necessary conditions for the inheritance and promotion of national music, and then gradually complete the inheritance and promotion of national music, and complete the protection of national music.

\section{Intangible cultural heritage}

According to the definition of UNESCO, intangible cultural heritage refers to all kinds of performances, performances, practice forms, knowledge system, skills and related tools, crafts and cultural places regarded as cultural heritage by groups, groups and individuals. Intangible cultural heritage is the result of continuous innovation in the process of human history changes. The sense of historical identity of groups and teams in the process of cohesion will stimulate human creativity and diversity of human history and culture to a certain extent. The common intangible cultural heritage includes oral language forms, art performance forms, traditional skills, traditional folk customs, traditional sports and entertainment, and the practice of knowledge about nature. Among them, national music belongs to the category of art performance forms. In the process of intangible cultural heritage protection, we need to pay attention to its national, dynamic, cultural, relative backwardness and vulnerability, and carry out targeted protection, inheritance and promotion. On the basis of cultural heritage protection, we should maximize the practicability, naturalness and unofficiality, so that it can continue in the wave of modern development without being assimilated or inherited Lost ${ }^{[1]}$.

\section{The protection of traditional music as intangible cultural heritage}

\subsection{Government protection and management is not enough}

The inheritance, protection and development of traditional music in intangible cultural heritage are complementary and indispensable. Our government attaches great importance to the protection and development of traditional music as intangible cultural heritage, and puts forward the concept of "cultural confidence" to promote economic development with cultural development. Local governments also actively respond to this call, vigorously strengthen the excavation of local traditional music and traditional culture, vigorously promote the development of World Heritage application, and hope to promote the local transmission through development and publicity Music, traditional culture to promote local economic and social development, attract more tourists to come to play, attract more capital to invest. However, excessive publicity and consumption of local traditional music and traditional culture will make the traditional music and traditional culture completely become the subsidiary of the economy,

Copyright (C) 2020 Jie Zhang

doi: 10.18282/1-e.v9i4.1689

This is an open-access article distributed under the terms of the Creative Commons Attribution Non-Commercial License (http://creativecommons.org/licenses/by-nc/4.0/), which permits unrestricted non-commercial use, distribution, and reproduction in any medium, provided the original work is properly cited. 
commercialized vassal and serious phenomenon of chasing fame and wealth. However, some local government departments are still not aware of this problem. They are still vigorously consuming local traditional music and traditional culture. They are eager to achieve the effect of developing local economy through publicity. However, they ignore the inheritance value of traditional music, which makes traditional music unable to be effectively inherited, It can only be consumed as an appendage of economic development, which restricts people's comprehensive understanding of traditional music. There are also some regions of the government aware of the importance of traditional music heritage, given a certain degree of attention to the protection of traditional music, but the management and publicity efforts are not enough, the protection of traditional music has not been implemented, the people's awareness of the protection and inheritance of traditional music is also very weak, making the traditional music can not be effectively protected and inherited. The protection of traditional music is a long-term work, which needs a lot of time and money. If the investment is not enough, the protection of traditional music can not be carried out continuously and smoothly, and it is difficult to achieve good results. Therefore, in order to strengthen the inheritance of intangible cultural heritage and the protection and development of traditional music, the government should take the lead and the public should work together to achieve results ${ }^{[2,3]}$.

\subsection{Lack of special rehearsal, performance venues and facilities}

For some large-scale orchestras or troupes, if they want to rehearse or perform traditional operas, they should not only provide fixed venues and professional facilities, but also spend a lot of money to buy musical instruments needed for training and performance. However, it is difficult to realize all the fixed places, professional facilities and equipment as well as expensive musical instruments purchase. Based on the above factors, it is not difficult to find that if we want to successfully rehearse and perform some traditional music that we are about to lose, we need to inject a lot of money into the investment in hardware facilities. However, the reality is that some groups which should continue to carry forward and inherit traditional music are facing the problem of insufficient funds, which leads to the failure of effective hardware solution and professional rehearsal and performance. They are not only difficult to get better development, but also facing the possibility of slow "withering" and even extinction ${ }^{[4]}$.

\section{Protection measures for traditional music as intangible cultural heritage}

\subsection{The government should promulgate and perfect relevant protection policies in time}

For the protection of traditional music of intangible cultural heritage, the government first needs to introduce relevant protection policies, and constantly improve the protection policies, to ensure that in the protection of traditional music, there are laws to abide by and the protection work can be carried out smoothly according to relevant policies. In 2011, the Chinese government issued laws and regulations related to the protection of intangible cultural heritage, which provides legal support for the intangible cultural heritage protection industry and makes the intangible cultural heritage protection work legal. Local governments have also followed the pace of the central government and formulated a series of protective laws and regulations in combination with the actual situation of local traditional culture and traditional music, strengthening the protection of traditional music and traditional culture $^{[5]}$.

\subsection{Strengthen publicity for the protection of traditional music}

The protection of intangible cultural heritage is a long way to go. It needs the unremitting efforts of the whole society and the full cooperation and protection of the broad masses of the people. Therefore, through radio, television, community billboards and other channels to let everyone know about traditional music, enter into traditional music, fall in love with traditional music, at the same time, improve the awareness of protecting traditional music and the importance of protecting the traditional music which is gradually disappearing in today's society. Only by improving the national consciousness, can we protect the traditional music in the intangible cultural heritage, and create a good environment for the inheritance of traditional music, so that the traditional music can be effectively spread and developed ${ }^{[6]}$.

\section{Conclusion}

National music is a kind of music with national characteristics and cultural and historical elements. Whether it can be formally included in the protection ranks of the International Intangible Cultural Heritage organization, it is an important cultural heritage in China, which should be treated with caution and should be inherited, promoted and protected. The ideological and cultural elements contained in national music are the key content of cultural heritage protection, and also the key point of national music inheritance and promotion. From this aspect, we can better protect national music.

\section{References}

[1] Wang Bo. Inheritance of Longdong folk music in college teaching from the perspective of Intangible Cultural Heritage [J]. Northern music, vol. 39, no. 6, pp. 127-128, 2019.

[2] Liu Qian, He Ping. Pursuit of socialist core values in the inheritance of Intangible Cultural Heritage [J]. National art research,vol. 29, no. 4, pp. 225-232, 2016.

[3] Shan Lili, Li Sha. Research on collaborative innovation mode of Sichuan Tibetan, Qiang and Yi Intangible Cultural Heritage

[J]. Science and technology management of land and resources,vol. 34, no. 6, pp. 54-61, 2017.

[4] Li Wenchun. Analysis on the path of inheriting intangible cultural heritage in kindergartens -- Taking Longyan Hakka intangible cultural heritage as an example [J]. Journal of Shaanxi Preschool Normal University, vol. 35, no. 10, pp. 19-23, 2019.

[5] Chen Wei, Liu Xiao. Research on the current situation and Countermeasures of the productive protection of the intangible cultural heritage of ethnic minorities in Southwest China [J]. Journal of Guilin Normal University,vol. 33, no. 6, pp. 60-65, 2019.

[6] Yu Yang, Dai Qiwen. Tourism development of intangible cultural heritage from the perspective of tourists [J]. Resource development and market,vol. 31, no. 4, pp. 472-476, 2015. 